\title{
Development of Guided Inquiry Models on Cooperative Learning Using Vocational School Materials LKS
}

\author{
Khamdun $^{1}$, Suparmi ${ }^{2}$, Maridi ${ }^{3}$, Ani Rusilowati ${ }^{4}$ \\ \{khamdun@umk.ac.id ${ }^{1}$ \} \\ ${ }^{1}$ Postgraduate Program Student, Universitas Sebelas Maret, Indonesia \\ ${ }^{1}$ Universitas Muria Kudus, Indonesia \\ ${ }^{2,3}$ Universitas Sebelas Maret, Indonesia \\ ${ }^{4}$ Universitas Negeri Semarang, Indonesia
}

\begin{abstract}
This study aims to develop a guided inquiry model in cooperative learning using the vocational school of Science. The data of this study are the results of the validation of the validator and the results of the trial analyzed with descriptive qualitative and quantitative techniques. The results of the validation showed that the development worksheet was in the good category. Process skills improve so it can be said that the developed worksheet is feasible and effective.
\end{abstract}

Keywords: guided inquiry model, cooperative learning, LKS

\section{PRELIMINARY}

Teaching and learning process is essentially a pattern of interaction between teachers and students and between students in an educational situation. In the teaching and learning process students play an active role in efforts to find knowledge, concepts, theories and conclusions is not an effort to gather information or facts. In order for this process to be carried out, the teacher's role is needed as a guide for teaching and learning activities so that students not only gain knowledge but are also able to build knowledge for themselves, so that student-centered learning is not teacher-centered (Depdiknas, 2006).

Facts on the ground based on the results of self-reflection as a teacher show that the learning process has not proceeded as desired as described above. The role of the teacher is still more dominant than students in science learning activities. The old learning paradigm centered on the teacher is still heavily carried out by the teacher, not much has shifted to constructivist views that involve more students. The teacher has not yet renewed the conventional science and technology learning methodologies that are commonly practiced by IPA teachers.

One learning approach that requires active student involvement in the learning process is the inquiry approach. Eggen \& theses from the results of the experiment and students can overcome the difficulties and obstacles during conducting the experimental activities.

Improving the concept of science can also be enhanced by guided inquiry learning, such as research conducted by Endang (2006). Guided inquiry learning will be easier for students if it 
is integrated with cooperative learning. Like research conducted by Bilgin (2009) which states that learning using guided inquiry combined with cooperative makes students more active in learning. with cooperative learning students will more easily find and understand difficult concepts if they can discuss each other's problems with their friends (Slavin, 1994). In line with research conducted by Okhee (2006) states that the inquiry method can improve student learning outcomes of low ability students on the subject matter of science evaporation. Manzoor (2009) states that teaching with an inquiry approach makes students interested in finding hypotheses on the results of experiments. With inquiry students can also find concepts (hypo-Kauchack (1996) stating inquiry is one of the effective ways that can help students improve thinking skills by using higher mental processes and critical thinking skills. In learning with inquiry, students in addition to mastering the concept of science, is also trained to research and solve a problem or question with existing facts, the statement is supported by the opinion of (Sadeh, 2009) stating that students who experience open inquiry can define phenomena, ask questions, hypotheses and plan In their inquiry, it is likely that they will be more dynamic, based on inquiry learning that is suitable for students in vocational high schools is guided inquiry, which is in line with research that has been done before, namely research conducted by Ali (2011) that implements inquiry learning and feedback. on science learning journals, da can improve the performance ability of students of class X SMK Kudus.

Another study was conducted by Christina \& Yovita (2006). In this research explained that guided inquiry combined with EIMA can bring up students' initial ideas, involve students in the learning process, involve students in exploring and reflecting on their ideas. Guided inquiry such as Patrick's research, et al (2009) can increase student motivation in learning science.

\section{METHOD}

This research was conducted at the Holy Vocational School. The form of this research is descriptive research with qualitative and quantitative data analysis. The development of this learning tool refers to the R\&D model with the $4 \mathrm{D}$ instructional design proposed by Thiagarajan (1974). 4D design consists of 4 stages, namely defining, designing, developing, and disseminating. This research is limited to the development stage

The scenario of the trial implementation implements the One Group Pretest-Postest Design (Tuckman, 1978) with the following pattern:

\section{$\mathrm{O} 1 \mathrm{X} \mathrm{O} 2$}

Information :

O1: Preliminary test, aims to measure students' learning abilities before learning takes place

$\mathrm{X}$ : The process of teaching and learning oriented to guided inquiry

O2: Final test, aims to measure students' learning abilities after learning takes place.

\section{RESULTS AND DISCUSSION}

The experimental activities carried out by students are contained in the Student Worksheet (LKS) on guided inquiry in cooperative learning. Where in guided inquiry learning students are actively involved in learning and discovering concepts through their own construction 
(constructivist learning theory). Cooperative learning is used because it is in accordance with Piaget's theory that students are encouraged to discover their own knowledge through interaction with their environment. The text "Student Worksheet" is written in all capital letters, times new roman font, font size 12, black (bold), and placed in the middle of the top. The titles of the LKS components are typed in uppercase and lower case letters, times new roman font size 12, and placed in the left-hand edge.

The use of the LKS writing structure as stated above, aims to make the LKS look neat and attractive, each component of the LKS can be seen clearly, and the LKS description is easy to read. Worksheets are developed for heat material, which consists of several components, namely Title, Basic Competence, Learning Objectives, and Worksheet Content. Following is the description of the revised LKS components, namely: a) LKS Title, Title of Student Worksheet (LKS) aims to differentiate between one LKS and another LKS. The revised LKS titles are LKS 1: Heat, LKS 2: Relationship Between The Amount of Heat with Temperature Change, Mass, and Specific Heat of The Substance, LKS 3: Influence of Heat to Change State of The Matter, and LKS 4: Heat Transfer; b) Student Identity, Student identity listed in the worksheet consists of: the name of the group, class, day and date of the practicum. The identity of students listed in this worksheet aims to facilitate teachers in assessment; c) Basic Competence, the formulation of basic competencies, shows the abilities that must be mastered by students after attending science subjects on the heat material. The basic competencies listed in the Worksheet are in accordance with the Basic Competencies listed in the RPP; d) Learning Objectives, The learning objectives listed in this worksheet are learning objectives for each sub-material in the worksheet listed in the lesson plan; e) The contents of the worksheets, Student Worksheets (LKS) produced in the form of worksheets are used by students as a guide for conducting experiments. The resulting worksheets based on guided inquiry approaches in cooperative learning, so that the contents of these worksheets consist of: formulating the problem, formulating hypotheses, tools and materials, experimental procedures, data tables. Data analysis, conclusions, and questions. In each worksheet content is provided a place for student answers to make it easier for students to write their answers.

The experimental procedure in this worksheet aims to make it easier for students to experiment in sequence. Provision of experimental procedures in LKS is in accordance with the method of guided inquiry, namely directing students to find or implement their own ideas but still in the guidance of the teacher.

In LKS there are also questions that aim to help students achieve the desired competencies. Many of the content components and questions in the worksheet aim to make students work in groups optimally. It also shows that group work is very necessary so students can complete all activities in the worksheet. This is consistent with the objectives of cooperative learning.

The student worksheet (LKS) resulting from the development provides an alternative learning strategy that is innovative, constructive, and student-centered, focusing on achieving the expected competencies. The components in the worksheet are expected to create an atmosphere of learning that is interactive, inspiring, fun, challenging, motivates students to participate actively, and provides sufficient space for initiative, creativity, and independence in accordance with their talents, interests, and physical and psychological development student.

The worksheet from the development also becomes a quality curriculum document, because it has passed the validation and trial stages, so that it is appropriate for students to use

\section{Grafik Hasil Validasi LKS}

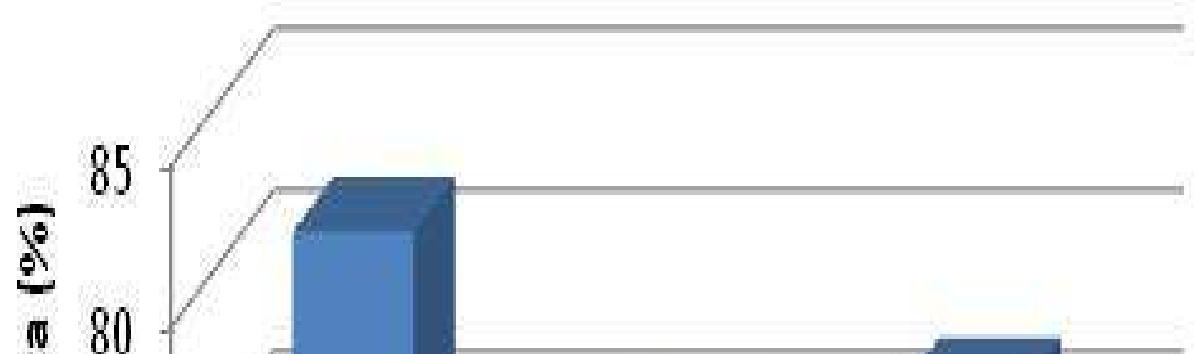


Gambar 1. Grafik Hasil Validasi LKS

\section{Grafil Penilaian Keterampilan Inkuiri Pala uji cola}

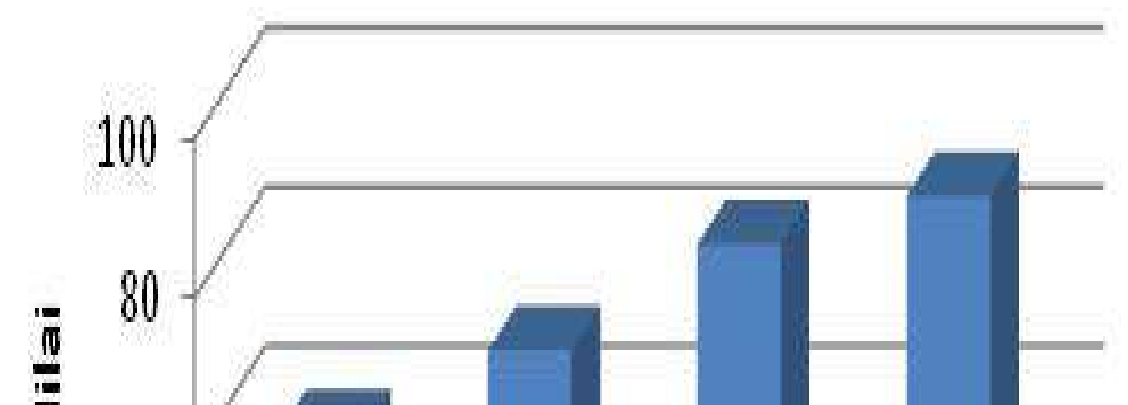


Gambar 2. Grafik Penilaian Inkuiri pada Uji Coba

Student Worksheet (LKS) is a guide for students in understanding the skills of the processes and concepts of the material being and will be studied. The Sis-wa Worksheet (LKS) developed based on guided inquiry consists of from the components: title, basic competencies, learning objectives, formulating problems, hypotheses, tools and materials, experimental steps, table of observations, data analysis, and conclusions.

LKS components that get the lowest ratings will be reviewed and improvements will be made. An expert response score will be analyzed to determine the feasibility of the worksheet. Data in the form of suggestions and comments written directly on the evaluation sheet are made into consideration and basis for improvement. Repairing the LKS component aims to reduce the fundamental errors of the LKS product. In general, the results of the assessment of the validator for Student Worksheets (LKS) are in a good category, which means the Student Worksheets (LKS) resulting from the development are feasible to use. The validation sheet of the Sis-wa Worksheet (LKS) consists of three elements, namely the feasibility of construction, the preservation of presentation, and the process skills component. The results of the validation of the Student Worksheet from the validator are presented in Figure 1.

Figure 1 shows, the percentage of elements of construction feasibility obtained a score of $81.3 \%$, which means very good, the percentage of elements of presentation worthiness obtained a score of $75 \%$, which means good, and the percentage of elements of the 
components of the process of achievement obtained a score of $76.7 \%$, which means good . Of the three elements that received the lowest rating was the serving feasibility, which was $75 \%$.

After the next development phase is tested on students and assessment of students' guided inquiry skills in the trials carried out is shown in Figure 2.

Figure 2 shows that the average value of students' guided inquiry skills in trials has increased in each learning activity.

\section{COVER}

Based on the results of validation and testing it can be concluded that the Student Worksheet (LKS) is categorized as good which means the Student Worksheet (LKS) resulting from the development is appropriate to be used.

Based on the notes when the trial has been carried out, to optimize the use of LKS provides the following suggestions: a) The allocation of time should be highly considered, given the implementation of guided inquiry-based learning in cooperative learning requires a lot of time; b) This worksheet is arranged according to the characteristics of students so that students are expected to be able to use it independently; c) Learning tools in the form of worksheets are not the only source of student learning, teachers should advise students to read other relevant sources

The development of guided inquiry-based learning tools does not carry out the dissemination stage. However, if desired for the dissemination process several things need to be considered, namely this learning device is arranged based on the characteristics of Kudus vocational students. If you want to be reproduced you should do a revision according to the characteristics of other users.

This product development has been carried out minor revisions in accordance with the recommendations of the valor-tor and students as users. But to further improve the quality of learning tools, they should be further revised and developed for other materials in science subjects.

\section{BIBLIOGRAPHY}

Bilgin, I. 2009. The effects of guided inquiry instruction incorporating a cooperative learning ap- proach on university students achievement of acid and base concepts and attitude toward guided inquiry instruction. Scientific Recearch and Essay. Vol.4 (10): 1038-1046.

Christina V.S. and Yovita. 2006. Using a Guided Inquiry and Modeling Instructional Framework (EIMA) to Support K-8 Preservice Science Teaching. USA: Michigan State University. 